\title{
TELO (V PODOBO) UJETO
}

Ključne besede: portretna fotografija, fotografski atelje, Aleksandrinke, poklicna dojilja, discipliniranje telesa

Pojem »telo « uporabljamo v najrazličnejših povezavah, v tem prispevku bo le-to $\mathrm{v}$ tesni navezi $\mathrm{z}$ videzom in trenutkom, če pa o njima razmišljamo skozi fotografijo, je potemtakem telo »zamrznjeno « v času. Ali z Barthesovimi besedami: »Fotografija reproducira v neskončnost nekaj, kar se je zgodilo samo enkrat: mehanično ponavlja, kar se eksistencialno ne more nikoli ponoviti.« (Barthes, 1992, 12). Da bi bolje razložili naravo fotografskega medija, povejmo, da je predmet treh praks: »Operator je fotograf. Spektator smo mi vsi, ki si po časopisih, knjigah, albumih, arhivih kopičimo zbirke fotografij. In tisti ali tisto, ki je ali kar je na fotografiji, je tarča, referent, nekakšen majhen simulaker, eídolon, ki ga izžareva predmet, ki bi ga prav rad imenoval spektrum fotografije, saj beseda $\mathrm{v}$ korenu ohranja povezavo s 'spektaklom'." (Barthes, 1992, 15). In ker se bomo ukvarjali s portretno fotografijo, nikakor ne moremo mimo analize istega avtorja: »Portretna fotografija je zaprto polje sil. Na njem se križajo, soočajo, iznakažajo štirje imaginarni registri. Pred objektivom sem hkrati: tisti, za katerega se imam, tisti, za katerega bi hotel, da me imajo, tisti, za katerega me ima fotograf, in tisti, katerega uporablja, da razkazuje svojo umetnost." (Barthes, 1992, 18). Ker pozornost $\mathrm{v}$ nadaljevanju namenjamo tudi posnetku, ki je nastal na Reki, ne bo odveč, če citiramo še hrvaškega poznavalca:

"Fotograf ne slika, ampak odslikava, zrcali stvarnost. Njegov izdelek se $v$ hrvaščini imenuje 'kipec'. Življenje na fotografiji je namreč obstalo kot kip, nekaj nestalnega je postalo stalno. Kar se je enkrat zgodilo, se ne more ponoviti. Fotografija je torej resna igra, pri kateri se od fotografa zahteva 
vrhunska napetost čutil, velika prožnost duha, ki mora bliskovito razločiti opaženo gradivo, ga urediti $v$ ravnovesje kadra, izenačiti kontraste ali svetlobne tone in nazadnje vse to opraviti v odločilnem trenutku ekspozicije, ki vsemu daje pomen. "(Maleković, 1996, b. p.)

Po drugi strani pa je telo, kot beremo v leposlovju, "posoda življenja« in če na fotografskem posnetku pozorno opazujemo v trenutku »zamrznjena telesa «, ali po Barthesu »tarče«, nas sociološki, psihološki, zgodovinski, antropološki in še kakšni vzgibi spodbujajo k odkrivanju življenjskih zgodb, ki so »ovekovečene« in navadno hranjene v družinskih albumih. Ta v času zamrznjena telesa - posode življenj lahko različnim raziskovalcem ponujajo vpogled $v$ individualno življenje le-teh in s pomočjo ustreznih metod odstirajo zgodovino na »mikro« ravni, hkrati pa razkrivajo tako imenovano neoprijemljivo, nematerialno, neotipljivo kulturno dediščino. Kultura se ne manifestira samo $\mathrm{v}$ materialnih oblikah, $\mathrm{v}$ predmetih, temveč tudi skozi neoprijemljive elemente. Ti se prenašajo iz generacije $\mathrm{v}$ generacijo $\mathrm{s}$ pomočjo jezika, s spomini ljudi, glasbo, gledališčem, vedenjem, gestami, navadami, šegami itd. in se manifestirajo skozi oblačilno kulturo, prehrano, bivalno kulturo, zdravilstvo, vedenjske vzorce ...

V zasebni zapuščini na Goriškem sta se ohranili fotografiji s preloma 19. v 20. stoletje, ki sta hkrati zanimivo sociološko pričevanje in pogled v zgodovino fotografije oz. fotografskih ateljejev, enega v naši neposredni bližini, na Reki, drugega mnogo dlje, namreč v Egiptu.

$\mathrm{Na}$ fotografiji (slika 1), ki je starejša po datumu nastanka, je fotografski aparat zabeležil dvojni dopasni portret, v ozadju stoji Jožef Šavor, rojen leta 1865, pred njim je njegova izvoljenka Katarina Stefanović, rojena leta 1877. Oba sta pražnje oblečena in ozaljšana s pripetim cvetjem, kar nedvomno potrjuje, da gre za izjemen dogodek v njunem življenju: poročno fotografijo. Jožef strmi predse v gledalca, Katarinin obraz je rahlo zamaknjen v našo desno in njen pogled zre $v$ daljavo. Najbrž je na fotografovo sugestijo zaradi bohotnih rokavov stopila $\mathrm{v}$ ospredje in $\mathrm{z}$ enim od njiju skoraj prekrila polovico Jožefovega telesa. Drugi rokav ji je fotograf »odrezal«, kakor je na desni tudi Jožefovega, v kar je operatorja prisilil izbrani pokončni format fotografije. 


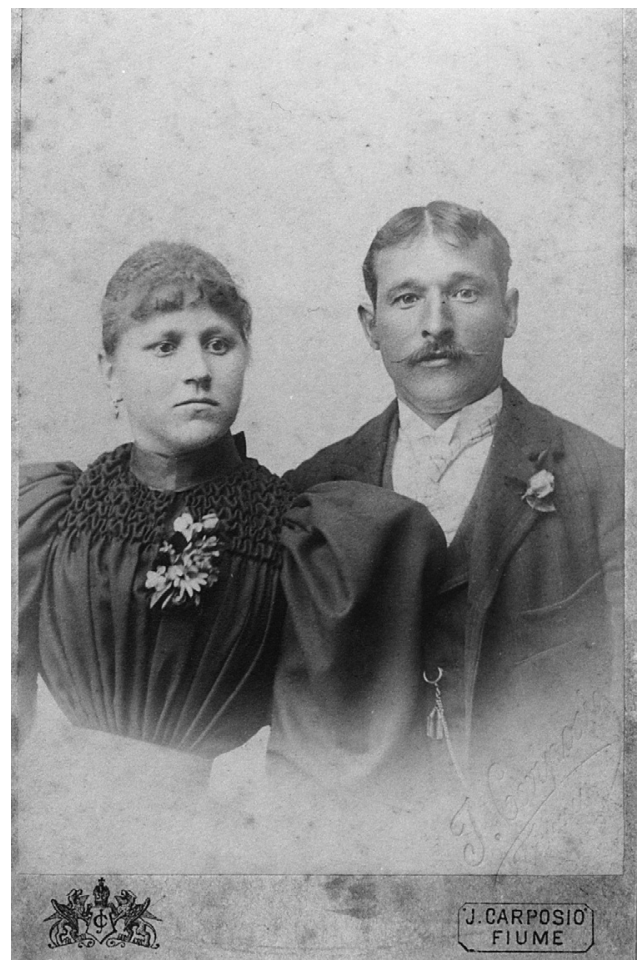

slika 1: Ilario Carposio, Katarina Stefanović, poročena Šavor in Jožef Šavor, 1895/1896, 10 x 15 cm, zasebna last.

Najbrž je fotografija nastala 1896 na Reki, kjer sta se mladoporočenca tudi spoznala. Siromašno in nepismeno Katarino (po enem pričevanju je bila rojena v Čičariji, po drugem pa na otoku Krku) ${ }^{1}$ so reški sorodniki povabili k sebi, da jim je pomagala $v$ gospodinjstvu, Jožef pa je prihajal kot sezonski delavec z Goriške (vas Vogrsko) in v hrvaškem obmorskem mestu vrtnaril. Povečan razvoj turizma je prinašal na Reko tudi modne novosti, ki jih je Katarina očitno poznala oziroma jih je nedvomno morala njena šivilja, kajti ko primerjamo nevestino bluzo z ilustracijami v knjigah, ki raziskujejo modo, najdemo iz tega časa prav take rokave »a prosciutto« (Black,

1 Iskreno se zahvaljujem naslednjim pričevalkam: Angeli Šavor (Tinina in Jožefova tudi že pokojna snaha) in njunima vnukinjama: Zorki Tavčar in Margariti Vanrechem. Prav tako sem dolžna zahvalo kolegu Luki Hribarju za pomoč pri skeniranju in kolegici Alenki Klemenc za vse tehtne predloge pri nastajanju članka. 
Garland, 1983, 218; prim. Ivoš, 2000, 361-362). To je hkrati dokaz, da si je Katarina prizadevala za družbeno promocijo, ki bi jo vsaj približala po zunanjem oblačilnem videzu premožnejšim slojem. Tu prepoznavamo enega izmed štirih Barthesovih $\mathrm{v}$ uvodu naštetih imaginarnih registrov, namreč pred objektivom je Tina tista, "za katero bi hotela, da jo imajo« (Barthes, 1992, 18). V tem primeru nam telo rabi kot nekakšen obešalnik za modno muho, ki se je pojavila okoli leta 1895 in posredno potrjuje prej omenjeno datacijo poroke. Tudi ustno izročilo pritegne tej dataciji: »Pet let nista imela otrok, prvorojenec je prišel na svet komaj leta 1900.« Po poroki je Jožef svojo ženo pripeljal iz obmorskega mesta v popolnoma ruralno področje, na vogrinsko kmetijo, kjer se je sčasoma naučila slovenščine, bolje rečeno vogrinskega narečja. Ker njeno drobno telo dalj časa ni moglo zanositi, ji je vaška zdravilka priporočila uživanje zelišč. Iz pripovedovanja njene snahe izpred več kot tridesetih let ni bilo mogoče zvedeti, katere ji je zdravilka

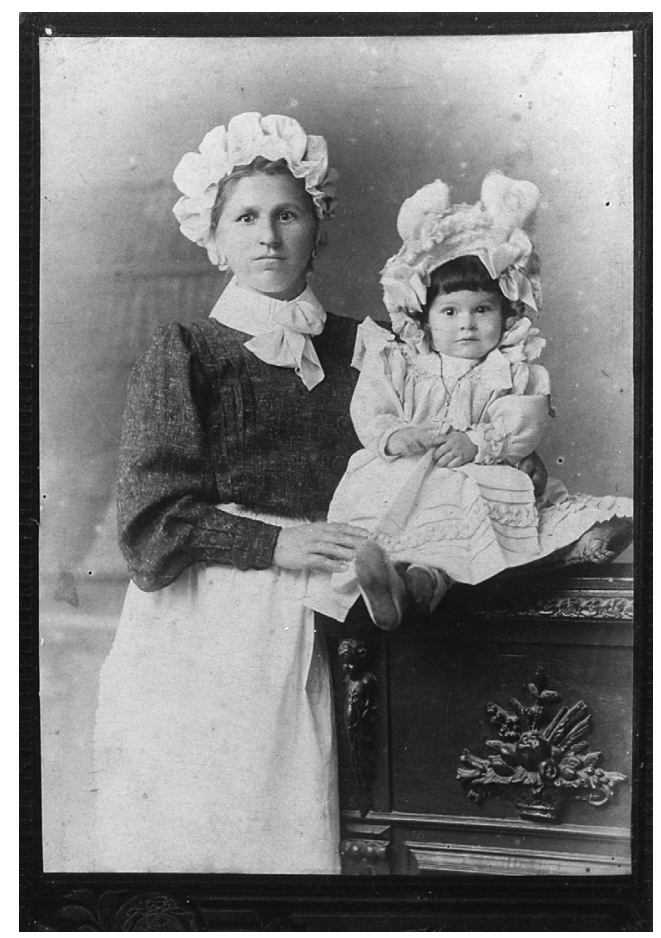

slika 2: Fettel\&Bernard, Katarina Šavor in otrok, $1906 / 8,10$ x 14,8 cm, zasebna last. 
svetovala. Katarina, po domače Tina, je za prvorojencem leta 1902 rodila deklico, dve leti pozneje dečka in leta 1906 ponovno dečka. In v tem času nastane druga fotografija (slika 2), na kateri je Tina okoli enajst let starejša. Fotografirana je skupaj z majhnim otrokom.

Njeno telo je še vedno vitko, kljub štirim porodom. Na glavi ima belo nagubano čepico, okoli vratu bel ovratnik s pentljo, oblečena je $\mathrm{v}$ temnejšo obleko, čez katero je od pasu navzdol prepasan bel predpasnik. Desno od nje na visoki omarici sedi enoleten ali dvoleten otrok, ves $v$ belih oblačilih, $\mathrm{z}$ nadvse bogato okrašeno kapico, okoli vratu mu visi verižica $\mathrm{z}$ ogromnim križem, izpod dolgega krila pa mu kukata podplata mehkih čeveljcev. Po Tinini opravi, ki prej spominja na uniformo kakor na kmečko obleko, in po otrokovih bogatih oblačilih je takoj jasno, da slika ni nastala v vaškem okolju, kjer je Tina živela po poroki. Ker iz ustnega izročila vemo, da je bila ena izmed mnogih žena in deklet $z$ Goriškega, ki so odšle na delo v Egipt, otrok na fotografiji torej ni njen, prav tako fotografija ni bila posneta v Avstro-Ogrski, temveč v Aleksandriji. Iskanje dela v tako oddaljeni deželi je bilo povezano $\mathrm{s}$ tamkajšnjim načrtovanjem in zatem gradnjo obsežnega kompleksa, kajti:

"Selitev bogatejših in bolj izobraženih evropskih družin (zdravniki, gradbeniki, inženirji) v Egipt se je začela ob izgradnji Sueškega prekopa (1869) in prva dekleta $z$ Goriškega so spremljale italijanske družine iz Trsta in Milana, pri katerih so tedaj služile, potem pa so skupaj $z$ njimi odšle $v$ Aleksandrijo ali Kairo. /.../Že v osemdesetih letih 19. stoletja je odhod deklet in žena $z$ Goriškega dobil množično obliko, saj se po dosedanjih zgodovinskih virih ocenjuje, da je bilo pred drugo svetovno vojno $v$ Aleksandriji 4500 Slovenk in v Kairu 1500.« (Koprivec, 2006, 97-98; prim. Makuc, 1990, 221)

Kot rečeno, so goriška dekleta in žene delale pri premožnih evropskih družinah kot dojilje, sobarice, varuške otrok, kot guvernante in spremljevalke žena bogatih poslovnežev. Že njihovi "poklici« kažejo na to, da so bile Aleksandrinke glede na zaposlitev socialno razslojene (Koprivec, 2006, 105).

Tina je postala poklicna dojilja, svoje telo, svoje mleko, je kmalu po porodu četrtega otroka ponudila novorojencu bogatih staršev in odstavila od prsi 
lastnega otroka, vse zaradi družinske ekonomske stiske. Vogrinska kmetija bi šla »na kant«, njena družina bi ostala brez strehe nad glavo, tako pa je za svoje telo, ki ga je prepustila »trgu delovne sile«, v zameno prejela mezdo, privarčevala je sredstva in preprečila najhujše, kar bi jih sicer doletelo. Doma je ob možu zapustila 6-letnega sina, 4-letno hčer, 2-letnega sina in novorojenca. Na tujem je bila potemtakem izvržena iz domače, tradicionalne skupnosti in bila brez zaščite družine in zakonskega moža, kar je bilo v kontradikciji s skoraj sočasnim Mahničevim razumevanjem podrejenosti ženske moškemu in skregano prav gotovo ne samo z njegovim pojmovanjem:

"Sicer je pri ženski še druga okoliščina, katera jo telesno podrejuje možu. Ženska je roditeljica otrok. Kot taka pa pride večkrat $v$ stan, $v$ katerem si telesno ne more opomoči. Žena je vže v nosečnosti šibka, da ne sme prevzemati težkih del, po porodu pa je tako onemogla, prve mesece sploh tako navezana na odgojo otroka, da je skoro nezmožna sama si skrbeti za hrano. Doba materinstva je pa sploh tudi doba, ko je ženska telesno najbolj razvita in najkrepkejša; in ravno $v$ tej dobi ona najbolj pogreša pomoči in - odvisnosti od moža. Zatorej je tudi Bog vže v sodbi, katero je izrekel nad prvo ženo, njeno odvisnost od moža nekako vtemeljil z razlogom, da bo porodnica: '... v bolečini boš rodila otroka in pod moževo oblastjo bodeš." (Mahnič, 1998, 3-4, 110; ponatisnjeno po Mahnič, 1893, 317-321)

Mahnič govori o »ženskah na sploh«, vendar so morale kmečke in delavske matere kmalu po rojstvu otroka poprijeti za delo in že s tem dejstvom je pisec prišel v nasprotje $\mathrm{z}$ realnostjo. ${ }^{2}$ Še več, neizprosna ekonomska nuja

2 Opozoriti je potrebno na zgodovinska dejstva (ne sicer iz naših krajev in tudi ne iz istega obdobja) o izjemno težkih razmerah, v katerih so delale nosečnice in porodnice: »Delavke v hitro rastočem industrijskem mestu Manchester, ki so morale v tridesetih letih 19. stoletja delati dvanajst do šestnajst ur na dan, da so zaslužile za eksistenčni minimum, so kljub bolečinam delale do dneva - ali celo do ure - poroda; potem so lahko v najboljšem primeru dva tedna ostale doma, mnoge pa zaradi pomanjkanja časa in podhranjenosti niso mogle dojiti otrok. Za varstvo dojenčkov so imele na voljo več možnosti. Lahko so jih prepustile starejšim otrokom, sorodnikom ali sosedom, in jim za to pogosto namenile del svoje borne plače. Ali pa so dajale otroku opij in lavdanum, da bi ga umirile, in ga pustile doma ali ga, če je bil še dojenček, med delom za statvami držale v naročju. V Angliji je bil zelo razširjen pojav baby-farming: revne ženske, ki si niso mogle privoščiti otroškega varstva, so novo- 
je pretrgala zakoreninjeno vlogo žensk in jih pričela osvobajati ne le izpod oblasti zakonskih mož, temveč tudi izpod vaškega nadzora župnikov. Prav slednji so v izseljevanju videli nevarnost za obstoj tradicionalne družine in verskega življenja. Goriška dekleta in žene so prevzele aktivno vlogo, postale so delavke, ki so iz tujine preživljale svoje družine in so zato tudi morale premagati marsikatero oviro. Če razčlenimo Mahničevo in tudi v takratni družbi zakoreninjeno razmišljanje, je Tina - poklicna dojilja - "prekršila« kar nekaj ustaljenih prepričanj: prvič, je takoj po porodu samostojno odpotovala v Aleksandrijo; drugič, »odpovedala « se je novorojencu in ga prepustila domači oskrbi; tretjič, poskrbela je ne le za lastno preživetje v tujini, temveč še več, tudi za preživetje domačih. Zato je nastal velik preobrat: zakonski mož je bil "priklenjen « na domačo kmetijo in postal odvisen od zakonske žene - poklicne dojilje in njene poslane mezde ter je ob obdelovanju zemlje moral poskrbeti še za nego in vzgojo otrok, ki je do tedaj tradicionalno pripadala ženi.

Ni natančno znano, koliko let je Tina služila v Aleksandriji. Vsekakor se je morala vrniti pred letom 1910, kajti takrat je doma rodila petega, zadnjega otroka. Morda pa je aleksandrinska fotografija $\mathrm{z}$ otrokom nastala ob slovesu, tik pred Tinino vrnitvijo v domovino? Kot je že bilo rečeno, ima fotografirani otrok eno ali dve leti, in vprašanje je, ali zgornja hipoteza zdrži, kajti ali je Tina v enem ali dveh letih dovolj zaslužila, da so doma poravnali vse terjatve, čeprav je po drugi strani znano, da so bile v Aleksandriji najbolje plačane prav dojilje. Ne na to ne na marsikatera druga vprašanja ni zanesljivih odgovorov. Pomisel, da če star Afričan umre, odnese s seboj del zgodovine, velja tudi za Tino - Aleksandrinko. Glede na križec, ki ga nosi otrok na fotografiji, lahko posredno sklepamo, da so bili Tinini delodajalci kristjani. Ker se Tina ni naučila pisati - tudi v visoki starosti se je podpisovala s križcem se sprašujemo, kako je vzdrževala stike z domačimi. Najbrž ji je kdo po nareku napisal pismo, in ko ga je prejela od doma, so ji vsebino prebrali. Če je torej preko posrednikov sporočala domačim novice, so te seveda najbrž ostajale na površinski ravni, nikakor pa ni mogla izražati svojih notranjih

rojenčke oddajale $\mathrm{v}$ posebne domove, kjer pa so z njimi tako slabo ravnali in je bila stopnja umrljivosti tako visoka, da je prišlo okoli leta 1870 do javnega škandala in do zakonodajnih reform.« (Bock, 2004, 154). 
stisk. Nobeno pismo ni ohranjeno, zato ni znano, kako je Tina doživljala geografske, klimatske, prehrambne, oblačilne, komunikacijske spremembe; morda ji je bilo nekoliko laže kot mnogim drugim dekletom in ženam z Goriške, ker je v zgodnji mladosti vendarle živela v jezikovno in kulturno raznolikem mestnem, reškem okolju. Zato predvidevamo, da se je v novem okolju sporazumevala s pogovorno italijanščino. Samo slutimo lahko, kaj je občutila do dodeljenega ji otroka, ki je sesal njeno mleko. Ponujajo se tri opcije: prvič, da je drobno telesce sprejela $\mathrm{z}$ odporom, drugič, da je bila do dojenčka ravnodušna, in tretjič, da ga je morda celo vzljubila. Vprašanje je, ali je pri negovanju in dojenju vsaj za trenutek pozabila na doma zapuščene otroke, ali jih je obratno ob teh opravilih še bolj pogrešala.

Nedvomno ji je delodajalec predpisal posebne higienske in prehrambne zahteve, ker je tako želel zavarovati otrokovo zdravje. $\mathrm{V}$ tem času so se $\mathrm{v}$ Evropi uveljavili ukrepi, povezani s »higienizacijo« - družbeno higieno ali, kot pravi M. Foucault, medicino socialnega prostora. »V ta sklop sodijo tudi ukrepi za preprečevanje epidemij, predpisi o stanovanjskih pogojih, skupaj z vse večjo težnjo po administrativnem uvajanju reda in nadzora nad populacijo« (Drglin, 2003, 35; prim. Foucault, 1984), ki se je s selitvijo premožnejših in izobraženih evropskih družin prav gotovo uveljavila tudi v Aleksandriji in Kairu. Prav tako ni znano, ali je bila Tina podvržena zdravniškim pregledom, če pa je bila, je to bilo prej zaradi skrbi za otrokovo, ne pa toliko za njeno zdravje. Če ta hipoteza drži, je bilo njeno telo v tem pogledu »na razpolago« delodajalcu. Nedvomno pa so dojiljo poučili o različnih režimih umivanja dojk, kajti v tem času so pričeli tiskati vse več tovrstnih navodil:

»Priprava na dojenje je bila stalnica: nasveti za utrjevanje bradavic so navzoči celo stoletje /.../, čeprav preverjeni podatki dokazujejo, da prsi ni treba posebej umivati z mrzlo vodo, razkuževati z različnimi razkužili, vsak dan vsaj enkrat frotirati z grobo brisačo in tako dalje. Navedene izjave lahko beremo $v$ luči trditev, da uveljavitev medicine kot znanosti neizogibno poveže povečano pomoč ljudem $z$ določenimi učinki gospostva in da ob prepoznavanju enega ne smemo spregledati drugega. Taka navodila lahko razumemo kot discipliniranje telesa /.../ Navodila in kodiranje gibov pri negi prsi pa bi lahko umestili v poizkus discipliniranja ženskih teles (podobne primere $v$ drugačnem kontekstu našteva M. Foucault v Nadzo- 
rovanju in kaznovanju). /.../ Discipliniranje telesa in duha hodita $z$ roko v roki.«(Drglin, 2003, 29; prim. Foucault, 1984).

Kot bomo videli nekoliko pozneje, se je Tina $\mathrm{z}$ otrokom fotografirala $\mathrm{v}$ prestižnem ateljeju in iz posnetka lahko razberemo, da je njeno telo oblečeno v nekakšno uniformo, ki jo je morala nositi tudi zunaj bivališča. Tako je bil njen status takoj razpoznaven in hierarhično razločevalen. V nasprotju s poročno fotografijo, kjer smo Tino prepoznali za tisto, »za katero bi hotela, da jo imajo « (Barthes, 1992, 18), jo pri tem posnetku prepoznamo kot tisto, »kakršno jo je hotel imeti delodajalec«. Tinina obleka - uniforma je slehernemu očesu kazala klasiranje, kot bi rekel Foucault: »Delitev po položajih ali stopnjah ima dvojno vlogo: zaznamuje odmike, hierarhizira lastnosti, zmožnosti in spretnosti; pa tudi kaznuje in nagrajuje." (Foucault, 1984, 181). Obleka je nekakšna »meja med sebstvom in ne-sebstvom, telesnim in socialnim " (Bahovec, 1995, 3-4, 37).

$\mathrm{Za}$ fotografiranje $\mathrm{v}$ aleksandrinskem ateljeju se je nedvomno odločil delodajalec, da bi ohranil spomin predvsem na otroka, posredno pa tudi na njegovo dojiljo in posnetek shranil v družinski album. Izvod fotografije je podaril tudi dojilji. Tina je fotografijo v baulu (potovalnem kovčku) prinesla na vogrinsko kmetijo in je ni razkazovala svojcem. Po prihodu v domovino se je morala spet prilagoditi, zdaj prav gotovo mnogo slabšim materialnim standardom, in v družini o njenem aleksandrinskem bivanju niso govorili. Njena vnukinja se spominja, da je kot deklica naskrivaj občudovala izredno lepo oblikovano in poslikano pahljačo, ki jo je Tina hranila kot spomin na aleksandrijske dni. Že to dejstvo priča, da niso ne Jožef ne Tina in ne njuni otroci hoteli obujati spominov na ta del njihovega življenja, zato so jih raje potlačili vase.

Od trpke življenjske zgodbe preidimo k ustvarjalcem obeh fotografij. Čeprav sta bila tako Tina kot Jožef Šavor pripadnika delavsko-kmečkega sloja, sta izbrala takrat pomemben in prestižen fotografski atelje kljub temu, da jih je v tem obdobju na Reki delovalo še kar nekaj. Fotografiral ju je Ilario Carposio (Trento, 1852 - Reka, 1921), ki je vrata svojega studia odprl leta 1878 in je kmalu postal priznan in spoštovan. Fotografovo ustvarjanje je dočakalo strokovno obravnavo in je bilo deležno posebne pozornosti, saj so mu v letu 2004 pripravili razstavo tako na Reki kot pozneje v Zagrebu in 
ugotovitve strnili v razstavnem katalogu (Smokvina, 2004, 5). ${ }^{3}$ Pred tem je nanj med drugimi opozorila tudi Marija Tonković in ga omenila med pomembnimi fotografi, ki so delovali na ozemlju Hrvaške (Tonković, 1996, b. p.). Ista avtorica je takole opredelila njegove in fotografske posnetke nekaterih kolegov, ki so se morali zaradi porajajočega turizma in izključno elitnih gostov meriti po kvaliteti svojih fotografij z velikimi središči: „Svetli, uglajeni 'platinotipijski' portreti s popolnoma čistim ozadjem prihajajo $\mathrm{v}$ tem obdobju iz Carposijeve, Verderberjeve in Letiševe delavnice ali iz delavnice Antonia d'Ancone.« (Tonković, 2003, 150). Po mnenju Miljenka Smokvine je Carposio po letu 1890 postal najboljši fotograf na Reki in tako rekoč ni imel prave konkurence (Smokvina, 2004, 9). Njegov fotografski atelje je bil v ulici St. Andrea, leta 1898 so jo preimenovali v čast dolgoletnemu županu v ulico Ciotta (Smokvina, 2004, 11). Gotovo sta Tina in Jožef o njegovem ateljeju, ki je bil lociran v bližini varieteja Riccottijevih, pozneje gledališča Fenice, slišala govoriti druge ali pa sta ga ob sprehodih tudi sama opazila. V tedanjem času je bil obisk pri fotografu del družbenega "glamourja» (Smokvina, 2004, 5), ta je zajel, kot dokazuje tudi naš dvojni fotografski portret, širok krog prebivalcev. Ime ulice, v kateri je bil Carposijev fotografski atelje, je za nas pomemben, saj na hrbtni strani posnetka natisnjena prvotna ulica, to je St. Andrea, dodatno dokazuje, da sta se mladoporočenca fotografirala pri njem pred letom 1898, torej pred preimenovanjem ulice. Carposio je nekako od 1894 do približno leta 1907 vse svoje fotografije opremil s kartoni, ki so imeli na hrbtišču natisnjene vse medalje, ki jih je avtor prejel.

Tako so tudi na portretu mladoporočencev na hrbtni strani fotografije predstavljene vse Carposijeve nagrade (slika 3). Pod njegovim grbom se vije na napisnem traku napis: Grande medaglia d'oro Napoli 1886, krožno od leve proti desni je natisnjen venec dvanajstih kolajn $\mathrm{z}$ napisnimi trakovi prepletenimi $\mathrm{z}$ olistanimi vejicami, $\mathrm{z}$ navedbami mest in letnicami pridobljenih nagrad. ${ }^{4} \mathrm{~V}$ osrednjem prostoru beremo: »PREMIATO STA-

3 Avtor domneva, da je imel Carposio ob prihodu na Reko 26 let. Najprej je delal pri G. Luzzattu, nato pa je kupil njegov studio. Prvič se je javnosti predstavil leta 1878 z oglasom $\mathrm{v} »$ La Bilanci«, kjer je samozavestno sporočal o svojem fotografskem znanju in ponudbi: »/.../ z maksimalno natančnostjo, ostrino /.../ in se ne boji izzivov /.../« Zahvaljujem se gospodu Goranu Crnkoviću, ravnatelju Državnega arhiva na Reki, za podarjeni in hitro poslani razstavni katalog Riječki fotografski studio Carposio 1878-1947.

4 Glej hrbtišče dvojnega portreta mladoporočencev Šavor. Carposio je bil za svoje fotografije 


\section{BILI - MENTO FOTOGRAFICO - CARPOSIO FIUME - SITO IN PIA-} NO TERRA VIA ST ANDREA«. Potrebno je tudi zapisati, da so na našem dvojnem fotografskem portretu kar štirikrat natisnjeni (recto, verso) Carposijev podpis ali njegovo ime in priimek v verzalkah oziroma njegove inicialke, kar je bilo v skladu, s takratno opremo posnetkov, o čemer je tudi za slovenske fotografe pisal Mirko Kambič: »Svoje stvaritve so opremljali z žigi in napisi ter drugimi podatki, obvezno seveda $\mathrm{z}$ imenom mojstra oziroma lastnika ateljeja." (Kambič, 1989, 18). Avtor dvojnega portreta se je podpisal poševno spodaj na desni strani - na Jožefov portret z: I. Carposio. $\mathrm{Na}$ isti strani spodaj je odtisnjen žig: J.Carposio Fiume in na levi, prav tako spodaj v grbu, ki ga sestavljata krilata leva in med njima postavljena krona, sta v osrednjem ščitku natisnjeni iniciali: $J C$.

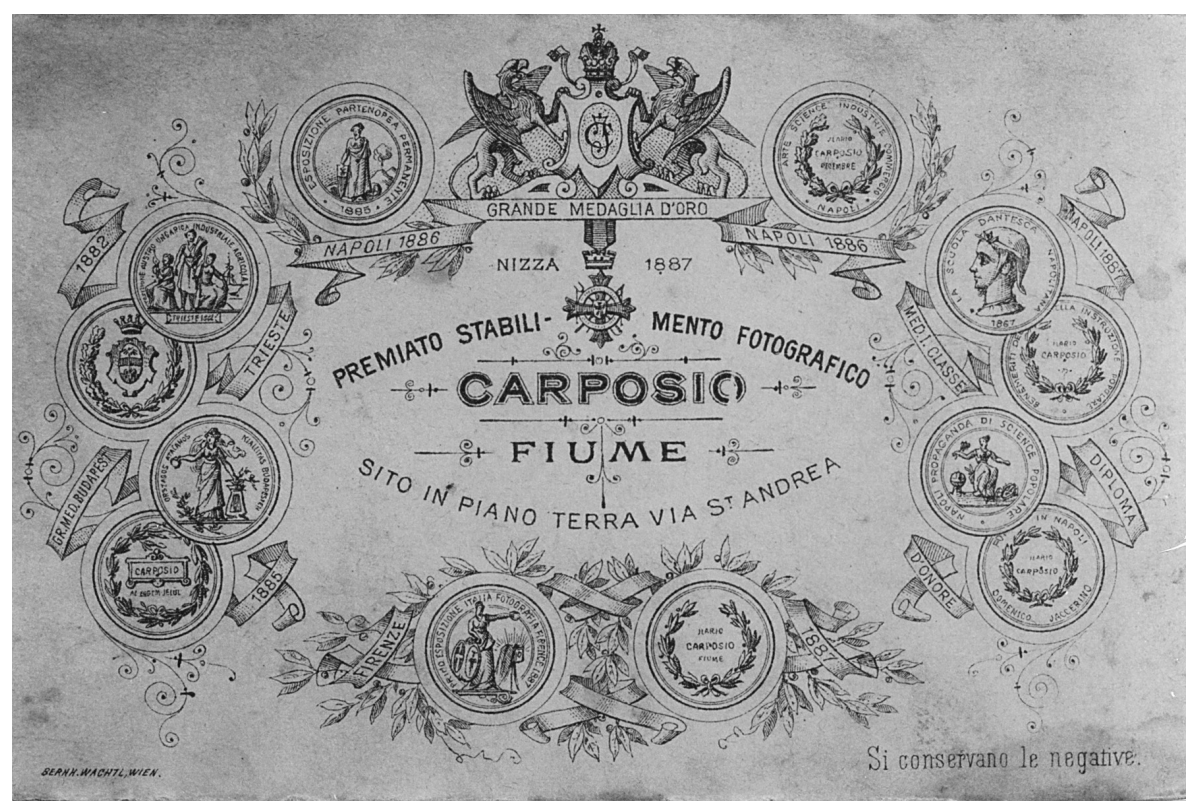

slika 3: Hrbtna stran reške fotografije.

večkrat nagrajen: leta 1882 je prejel medaljo v Trstu; leta 1885 v Budimpešti; leta 1886, zlato nagrado $\mathrm{v}$ Neaplju; naslednje leto je prejel $\mathrm{v}$ istem mestu medaljo prvega razreda; leta 1887 je dobil veliko zlato medaljo v Nici; leta 1887 so mu podelili nagrado v Firencah, kjer je razstavljal v dobri družbi. Glavna atrakcija razstave je bil pariški fotograf Nadar (Smokvina, 2004, 9). 
Ta poročna fotografija, ki se je »skrivala« v družinskem albumu okoli 113 let, ni samo izsek iz zgodovine neke družine, temveč tudi dokument o tedanji reški fotografiji in prebivalcih mesta, čeprav samo sezonskih, ki pa so kljub vsemu soustvarjali podobo obmorskega, jezikovno in kulturno raznolikega kraja.

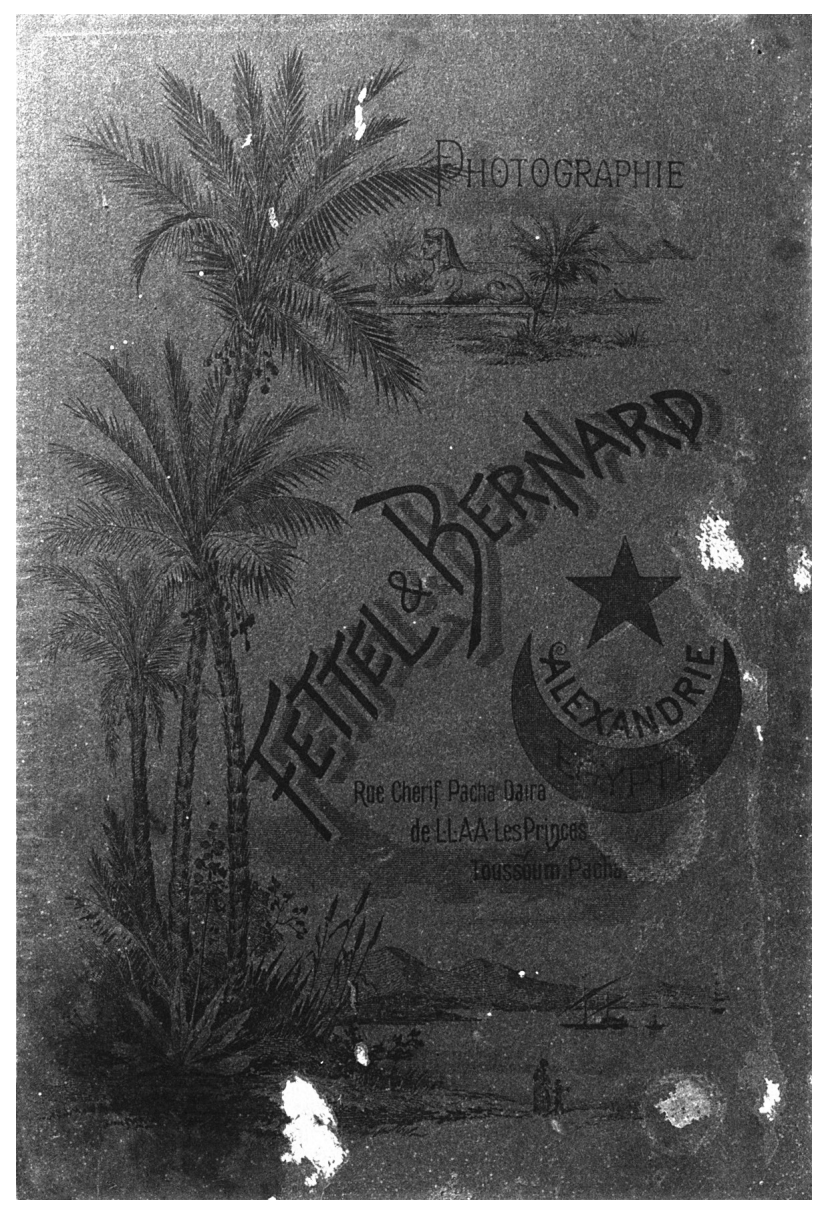

slika 4: Hrbtna stran aleksandrinske fotografije. 
Aleksandrinska fotografija je nastala $\mathrm{v}$ fotografskem ateljeju Fettel \& Bernard, ki je glede na ohranjene fotografije deloval nekako od leta $1885^{5}$ in vsaj do leta 1906/8, kot je predlagana datacija obravnavane fotografije. Za sedaj o ateljeju ni mogoče kaj več povedati. Primerjava kartonastih hrbtišč zgodnejših posnetkov (glej elektronski naslov) z našo fotografijo (slika 4) dokazuje, da so se sicer vsebinsko isti napisi oblikovno spreminjali in $\mathrm{v}$ našem primeru dopolnili $\mathrm{z}$ ilustracijo palm, drugega rastlinja, $\mathrm{z}$ obalo in sprehajalcema ter hribovjem v ozadju, čolnom na vodni gladini, zgoraj s sfingo. Napis, že spet natisnjen z drugimi črkami, pa je vsebinsko isti: PHOTOGRAPHIE FETTEL\&BERNARD ALEXANDRIE EGYPT. V ateljeju so ohranjali iste rekvizite daljše obdobje, kar nam dokazuje primerjava fotografije, nastale v istem ateljeju leta 1896, z našo. Na starejšem posnetku je predstavljen grški pesnik Constantine P. Cavafy (1863-1933), ki je v tem času živel v Aleksandriji in je ob nastanku fotografije služboval v vladni pisarni na enem izmed ministrstev. ${ }^{6}$ Mladi pesnik je predstavljen v elegantnem oblačilu, kot gentleman tistega časa, v desnici drži sprehajalno palico in klobuk. Naslanja se ob omarico, ki je identična tisti, ob kateri stoji Tina in objema na omarici sedečega otroka. Sicer je v drugem primeru fotograf zajel le zgornji del tega pohištvenega kosa $\mathrm{z}$ izrezljanim fantičem na vogalu in s cvetličnim tihožitjem na osrednjem delu, medtem ko je pesnikovo telo zajeto celopostavno s celotnim ateljejskim rekvizitom, na katerem sta razločno vidna isti izrezljani fantič in tihožitje. Na omarici sloni pesnikova levica, pod njo pa je podstavljena knjiga, ki je prav gotovo atribut njegovega »pesniškega poklica«. Analogno njegovemu atributu je na istem mestu na drugi fotografiji postavljen atribut Tininega "poklica» - otrok, ki ga je dobro hranila s svojim mlekom, sodeč po njegovem zdravem in okrogloličnem obrazu. Kakšno naključje, da sta se ob isti omarici fotografirala pesnik in nepismena Aleksandrinka; in še drugi kontrast v istem ateljeju so se srečevali ljudje iz vrha in $\mathrm{z}$ dna družbene lestvice.

5 Http://www.acgart.gr/ACG-COLLECTION/ARTISTS/F/FeBe/FeBe-art.htm. Na tem elektronskem naslovu so objavljene tri fotografije iz fotografskega ateljeja Fettel\&Bernard, ki so datirane, dve v leto 1885 in ena v leto 1890.

6 Prim. http://www.lsa.umich.edu/kelsey/galleries/Exhibits/cavafy/intro.html in http://cavafis.compupress.gr/cavafyl8.htm. 
Pred leti je v razstavnem katalogu o fotografiji avtor uvod naslovil Fragmenti planetarnega spomina (Kovič, 1989, 6); naj bosta v tem prispevku obravnavani fotografiji kapljici v morje k zapolnjevanju vrzeli v tem specifičnem planetarnem spominu.

\section{VIRI}

Družinski album, zasebna last

http://www.acgart.gr/ACG-COLLECTION/ARTISTS/F/FeBe/FeBe-art.htm http://cavafis.compupress.gr/cavafy18.htm

http://www.lsa.umich.edu/kelsey/galleries/Exhibits/cavafy/intro.html

\section{LITERATURA}

Eva D. Bahovec, Žensko telo in oblast v mediju vizualnega. Degradacija pogleda v sodobni feministični misli?, Delta, Ljubljana 1995, 3-4.

Roland Barthes, Camera lucida. Zapiski o fotografiji, Studia Humanitatis, ŠKUC, Filozofska fakulteta, Ljubljana 1992.

Anderson Black, Madge Garland, La moda grande storia illustrata, De Agostini, Novara 1983.

Gisela Bock, Ženske v evropski zgodovini, ${ }^{\star}$ cf., Ljubljana 2004.

Zalka Drglin, Rojstna hiša: Kulturna anatomija poroda, Delta, Ljubljana 2003.

Michel Foucault, Nadzorovanje in kaznovanje, Delavska enotnost, Ljubljana 1984.

Jelena Ivoš, Historicizam i moda, v: Historicizam u Hrvatskoj, I., Muzej za umjetnost i obrt, Zagreb 2000. 
Mirko Kambič, Ateljejska fotografija na Slovenskem 1859-1919, v: 150 let fotografije na Slovenskem 1839-1919, Mestna galerija Ljubljana, Arhitekturni muzej Ljubljana, Ljubljana 1989.

Daša Koprivec, Aleksandrinke - življenje v Egiptu in doma, Etnolog, 16, Slovenski etnografski muzej, Ljubljana 2006.

Brane Kovič, Fragmenti planetarnega spomina, v: 150 let Fotografije na Slovenskem, Mestna galerija, Arhitekturni muzej Ljubljana, Ljubljana 1989.

Anton Mahnič, Žensko poglavje: zakaj je prav in naravno, da je žena podrejena možu?, Delta, Ljubljana 1998, št. 3-4. Ponatisnjeno po Mahnič, A., Žensko poglavje, Rimski katolik, Peti tečaj, Gorica 1893.

Dorica Makuc, Izseljenci v Egiptu, v: Enciklopedija Slovenije, zv. 4, Mladinska knjiga 1990.

Vladimir Maleković, Hrvaška kot civilizacijski in kulturni okvir razvoja fotografije 1848-1951, v: Fotografija na Hrvaškem 1848-1951, Narodna galerija, Ljubljana, Muzej za umjetnost i obrt, Zagreb 1996.

Miljenko Smokvina, Riječki fotografski studio Carposio 1878-1947, Državni arhiv u Rijeci, Rijeka 2004.

Marija Tonković, Oris zgodovine fotografije na Hrvaškem, v: Fotografija na Hrvaškem 1848-1951, Narodna galerija, Ljubljana 1996.

Marija Tonković, Drugačije slike sjećanja: fotografija od poze do pokrenute slike, v: Secesija u Hrvatskoj, Muzej za umjetnost i obrt, Zagreb 2003. 


\title{
THE BODY CAUGHT IN AN IMAGE
}

Key Words: portrait photography, photographic studio, Slovene women emigrants in Egypt (Aleksandrinke), professional wet nurse, disciplined body

\begin{abstract}
In a private collection in Nova Gorica, Slovenia, two photographs from the beginning of the twentieth century have been preserved that are interesting as both sociological evidence and documentation of the history of photography; specifically, that of two photography studios: one in Rijeka, Croatia, and the other in the faraway Egypt. The persons in these photos are "bodies frozen in time," but at the same time they are "holders of lives." They offer an insight into their individual lifestyles and, by applying appropriate methods, they unveil history at the "micro" level. This paper discusses the "vocation" of a wet nurse in Alexandria (born in 1877), one of numerous women from the Gorizia region that left their homeland to earn their living in a faraway country out of economic necessity. The focus is on the issue of her body, which, in the case of the earlier photograph taken on the occasion of her wedding, serves as a clothes-hanger for a fashionable dress, whereas the second photograph was taken after she had been forced to offer her body to the "labor market," receiving wages in return for having weaned her own child and going to Alexandria to suckle the baby of rich parents there. Along with this bitter central theme, the creators of the two photographs are also studied: the older photo was taken in 1895/96 in Rijeka by Ilario Carposio (1852-1921), who received several international awards for his trade, which he also documented on the verso of the photograph. The second photo was taken at the Fettel \& Bernard studio in Alexandria. By a strange coincidence, both the Alexandria wet nurse (in 1906/07) and, a decade earlier (in 1896), the Greek poet Constantin P. Cavafy (1863-1933) were photographed in the same studio, posed next to the same studio requisite, which demonstrates that people of both upper and lower classes could meet in these studios.
\end{abstract}

